enjoyed after the long winter diet of water-soured and stale poplar logs and willow brush. At the west farm too, yesterday, a big lazy Black Bear just sat on his tail beside the grain bin and watched the boys working up the soil with their John Deere. He also, is really enjoying the spring weather, while the Deer graze here and there, seeming not to be satisfied to eat in one place for even a half minute, but to find something just a little better further along.

The wheat is showing in the rows; the rhubarb is nearly ready for the pie, and the patch of Wild Onionsfor those who like onions are just right for a sandwich.

As soon as the crop and gardens are all in, and the fences fixed, we'll be heading for the "Lake" to do a bit of fishing, fix up the cabin, for almost before we know it, it will be midsummer and the "First of July."

\title{
Seen From a City Window
}

\author{
Horace and Frances Croome, Regina
}

Our lot is only 25 feet by 125 feet but what a number of feathered visitors come for food-water-to bathe and to bask in the sunshine along the fence! Even a bee had a bath one day!

Just outside the dining room window are a plum tree, a bird bath and a feeding tray. All winter we kept pieces of suet-fat tied to the tree branches. Ham rind fat seemed a special favorite as well as fat from the neck skin of a chicken that we stuck on a thorn of the tree. On the feeding tray, as well as the usual crumbs, we put out a beef bone, fish bones and fishy skin. As they picked away at these, what a chance we had to watch them!

The first to touch the bones was an Olive-backed Thrush-then a Robin. After the first day they would peckpeck away, then fly off to a tree or fence for a sunning. Of course there were numbers of sparrows always around. We were surprised to see how early in the season they started to bathe in the bird bath. We would pour warm water on the thin ice and soon-down they would come.

When the plum tree was in full bloom and the air filled with fragrance, the bees and insects hovered over it almost like a cloud.

Birds that we have seen and indentified are Robins, Olive-backed Thrush, Juncos, Tree Sparrows, White-crowned Sparrow, Yellow Warblers, Baltimore Oriole and Grackle.

Later in the season on the plum tree, we put bits of soft string and colored wool. It all disappeared. Then we put out shredded rope. The rope seemed just what the Baltimore Oriole wanted, for he would come time and time again-to fill his beak and away he would fly.

One day a Grackle came to the bird bath with a large crust that he dipped and turned over in the water before he ate it. Some he carried away.

None of the birds seemed to notice us at the window unless we make a sudden movement-then away they fly. 